\title{
Antimacrofouling Assays of Sargassum duplicatum Extract in the Settlement Inhibition of Balanus sp. on Wooden Plank Substrate
}

\author{
Fahruddin Fahruddin*, Eva Johannes, Zaraswati Dwyana, \\ and Nur Haedar
}

Department of Biology, Faculty of Mathematics and Natural Sciences, Hasanuddin University, Makassar 90245, Indonesia

*Corresponding author.E-mail: fahruddin_science@unhas.ac.id https://doi.org/10.12982/CMUJNS.2020.0035

\author{
Received: November 29, 2019 \\ Revised: January 13, 2020 \\ Accepted: March 3, 2019
}

\begin{abstract}
Marine macro-biofouling by Balanus sp. is a source of problems in marine industry. Chemicals have been employed in dealing with biofouling, but are harmful to the environment. The bioactive compounds in seaweeds offer an environment-friendly anti-biofouling alternative. The aim of this study was to examine the ability of Sargassum duplicatum crude extract to inhibit macrofouling by Balanus sp. S. duplicatum was extracted by using the maceration method. Balanus sp. settlement inhibition assays were conducted by applying extract on wooden planks at varying extract and paint ratios. The wooden planks were later immersed in the seawater. Observation of the number of Balanus sp. attached on the planks was carried out after 10, 20, and 30 days of immersion in seawater. The results from the observation showed that treatment P4 (75\% extract, 25\% paint) was the most effective in inhibiting macrofouling by Balanus sp. This was evident from the 10-day and 30-day observations in which the number of Balanus sp. attached was only 12.3 or $3 \%$. The number was lower compared to in other treatments in 30-day observation, i.e., treatment P3 (50\% extract, 50\% paint) at 24 or 6\%, treatment P5 (100\% extract) at 48.3 or $12 \%$, P2 (25\% extract, $75 \%$ paint) at 73.6 or $19 \%$, treatment P1 (100\% paint) at 102 or 26\%, and control P6 (no paint and extract) at 135.6 or $34 \%$. For this reason, $S$. duplicatum extract was considered to have the potential to be developed as an anti-fouling agent on marine materials.
\end{abstract}

Keywords: Biofouling, Antifouling, Wooden plank, Sargassum duplicatum, Balanus sp. 


\section{INTRODUCTION}

The sea hosts a variety of marine organisms that naturally adhere to materials immersed in water and cause biological fouling and damage to such materials. This is referred to as biofouling or the adverse growth of marine organisms on immersed artificial structures, such as ship hulls, jetty pilings, navigational instruments, aquaculture net cages, and seawater pipes as well as wooden poles of coastal structures (Fusetani, 2004).

These organisms typically belong to bacterium, plant, and animal groups. In general, biofouling can be divided into two types: microfouling, which involves many microorganisms, especially bacteria, and macrofouling, which involves organisms like barnacles (Balanus sp.) (Almeida et al., 2007; Schultz, 2007).

Macrofouling involves algae and invertebrates like soft corals, sponges, anemones, tunicates, hydroids, barnacles, mussels, tubeworms, bryozoans, and seaweeds (Bannistera et al., 2019). These organisms live in attached colonies and cause damage to materials in the sea, leading to important problems in marine technology due to cost implications in the marine environment and artificial materials (Almeida et al., 2007).

Balanus sp. is a type of fouling organisms belonging to the Crustacea group in the sea. Balanus sp. adheres to a substrate by secreting a substance that is capable of inflicting damages to its host (Yule and Walker, 1984). The damage shortens the life of coastal constructions and ships, sends operating costs up, and corrodes substrates (Anil et al., 1995; Bannister et al., 2019). Marine biofouling has been causing significant losses as it shortens the service life of marine equipment (Silkina et al., 2009).

Over these years, biofouling of coastal structures or ships are handled with tributyltin-based anti-fouling paints, which have been proven effective but causing side effects to the environment for their toxicity to non-target organism and for their accumulative and mutagenic nature (Burgess et al., 2003; Bangkedphol et al., 2009; Kotrikla, 2009; Silkina et al., 2009; Pereira et al., 2019). Widespread uses of the commercial anti-fouling agent tributyltin (TBT) in maritime industries can directly and indirectly increase the heavy metal contents in sea environment (Boxall et al., 2000; Giacomazzi and Cochet, 2004). This agent is toxic to marine biota and has the potential to damage marine ecosystems (Clare et al., 1999; Evans et al., 2000; Fernandez et al., 2005).

TBT was ultimately banned in many countries (Bellas, 2006), with the International Maritime Organization issuing a resolution on the restriction of the use of TBT-based paints on ships (IMO, 2002). Other harmful chemicals that are frequently used as anti-fouling agents in paints are arsenic, organo-mercury, DDT, and lead (Evans et al., 2000; Fernandez et al., 2005; Kotrikla, 2009). Therefore, a breakthrough is needed to replace chemical materials for paint with natural and environmentally friendly materials. 
Physical and chemical methods come with several disadvantages. Biological methods as natural natural in biofouling handling are needed to produce eco friendly anti-fouling compounds (Yebra et al., 2004; Perez et al., 2006). Several kinds of natural anti-fouling agents that possess the ability to inhibit the growth of fouling organisms have been isolated from marine organisms like bacteria and marine algae (Abarzua and Jakubowski, 1995; Silkina et al., 2009).

Marine bioactive compounds can provide a good and environmentally friendly anti-fouling alternative to existing chemicals (Silkina et al., 2009). Sargassum, a seaweed from the brown algae group (Ochrophyta), is known to contain plenty of bioactive compounds, which are good at deterring the growth of the organism (Sastry and Rao, 1994). Seaweeds, notably Sargassum, are able to release secondary metabolites during metabolism for self-defense against predators and pests. The bioactive compounds produced by Sargassum are effective in protecting them from predators and bacteria (Santi et al., 2014). For the bioactive properties it possesses, Sargassum is seen to have the potential to be a marine anti-fouling source (Hellio et al., 2001).

The Sargassum diversity in Indonesia is quite vast, with 12 species that been identified, namely, Sargassum duplicatum, S. histrix, S. echinocarpum, S. gracilimun, S. obtusifolium, S. binderi, S. polycystum, S. crassifolium, S. microphylum, S. aquofilum, S. vulgare, and S. polyceratium (Kadi, 2005). This rich diversity is very conducive for the development of naturally sourced antifouling agents.

One of the Sargassum species that has been widely studied for their bioactive compounds is Sargassum duplicatum (Johnson et al., 2019). It contains a wide variety of chemicals with a great number of potential applications in the biotechnology industry, including as antifouling agent (Hellio et al., 2001; Chambers et al., 2006). Thus, it was considered necessary to conduct assays to find out the potential of $S$. duplicatum crude extract to inhibit fouling by marine organisms like Balanus sp.

\section{MATERIALS AND METHODS}

\section{Sampling of $S$. duplicatum}

Samples of the seaweed $S$. duplicatum (Figure 1) were collected in situ from Barang Lompo Island, Makassar, South Sulawesi, Indonesia, where large beds of $S$. duplicatum and other seaweeds were present in abundance. The samples were collected from 2 to $6 \mathrm{~m}$ depth by scuba-diving. The samples were kept in plastic bags. In the laboratory, specimens were washed and cleaned of epiphytes, sand, and any attached material, then placed at room temperature in the shade to air-dry. The samples were stored at $-20{ }^{\circ} \mathrm{C}$ prior to extraction. Dried teak wooden plank ( $25 \mathrm{~cm} \times 35 \mathrm{~cm}$ in size) was used as a substrate. Commercial green-colored paint that was used was marine paint that was known as alkyd 
paints that contain biocides, which are most commonly used to paint ships sides or to coat the boats.

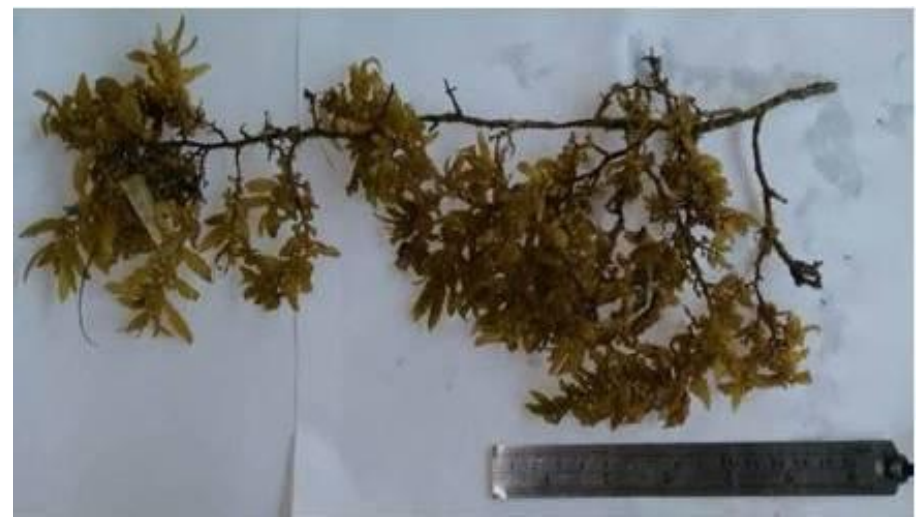

Figure 1. The samples of seaweed $S$. duplicatum that were collected from the beach of Barrang Lompo Island, Makassar, South Sulawesi, Indonesia.

\section{S. duplicatum extraction}

Extraction of $S$. duplicatum was conducted using the maceration method (Fahruddin et al., 2019). Methanol (1:3 w/v) was used as an extraction solvent for dried $S$. duplicatum. Samples were placed in $60{ }^{\circ} \mathrm{C}$ water bath for 24 hours, then filtered using fast qualitative filter paper Whatman No. 1. The filtrate was stored at $10{ }^{\circ} \mathrm{C}$, then concentrated with a rotary evaporator. S. duplicatum extract solution was prepared by dissolving $0.01 \mathrm{mg} / \mathrm{L}$ of extract with $2 \mathrm{~mL}$ of methanol and after that, homogenized using a vortex mixer. The formula used to calculate the extract yield is as follows:

$$
E Y V(\%)=\frac{X 2}{X 1} \times 100 \%
$$

where EYV is the extract yield value (\%), $X 1$ is the initial sample weight, and $X 2$ is the final weight (extract value).

\section{S. duplicatum extract treatments and anti-macrofouling assays}

Treatments were established by mixing the S. duplicatum extract solution with paint in the following ratios: P1: $100 \%$ paint; P2: $25 \%$ extract, $75 \%$ paint; P3: $50 \%$ extract, $50 \%$ paint; $\mathrm{P} 4: 75 \%$ extract, $25 \%$ paint; P5: $100 \%$ extract; and P6: control (no paint and extract). For additional information, 100\% of extract concentration is equivalent $0.005 \mathrm{mg} / \mathrm{mL}$ of methanol. Every treatment was applied on a teak plank substrate with a brush and was left for 4-5 hours to dry. Afterwards, the plank was immersed into the seawater near a deck at 1-1.5 m depth with a suspension rope at the same site at Popsa dock, Makassar, South Sulawesi, Indonesia (Figure 2). All treatments were performed in triplicate, resulting in comparable results. Observation of the number of organisms attached 
to the plank was conducted on day 10 , day 20 , and day 30 . Immersing the treatment was only until the $30^{\text {th }}$ day, because the maximum Balanus $\mathrm{sp}$. attachment occurs on 20-25 ${ }^{\text {th }}$ days (Minchinton and McKenzie, 2008). The average number of Balanus sp. attached to every plank was counted manually with the help of a loop (Figure 3).

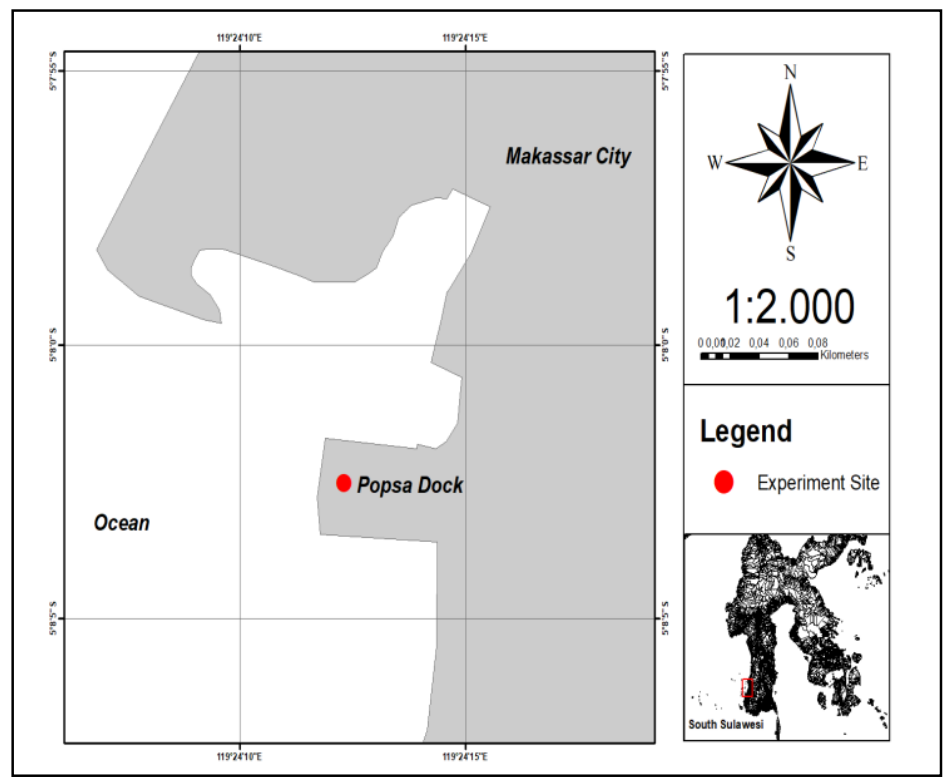

Figure 2. Map and the experiment site of anti-macrofouling activity at Popsa dock, Makassar, South Sulawesi, Indonesia.

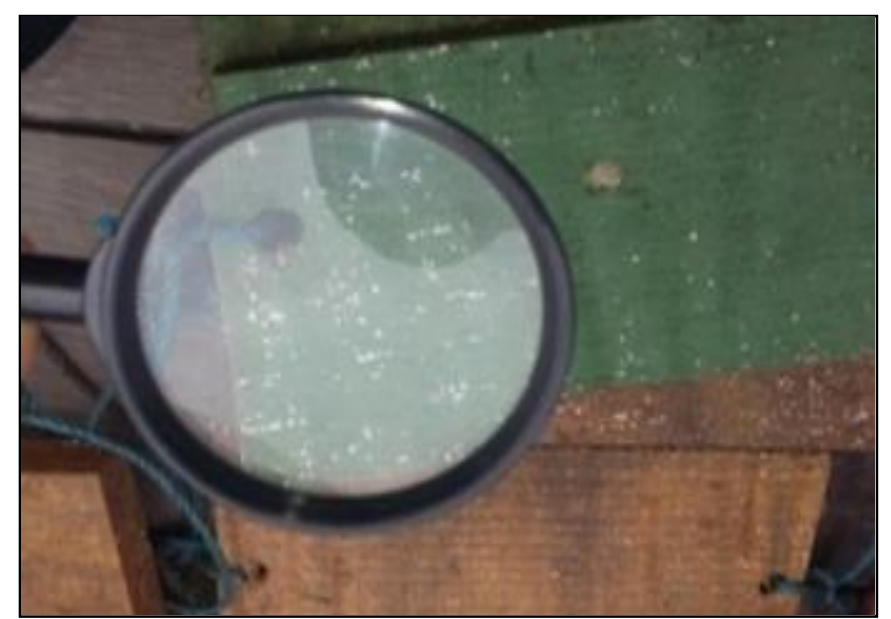

Figure 3. Visualization of the number of Balanus sp. attached to plank using loop. 


\section{S. duplicatum extraction}

\section{RESULTS}

A S. duplicatum extract yield value of $27.6 \%$ was obtained from the extract weight of $85 \mathrm{~g}$ that was divided by the dry weight of $306 \mathrm{~g}$ and then multiplied by $100 \%$. The extract yield value was considered high based on the resulted weight, which did not differ much from the initial weight. This suggested that a high value of polar bioactive compounds was contained in the S. duplicatum.

\section{Anti-macrofouling activity}

From the observation on day 10, it was found that the wooden planks treated with $S$. duplicatum extract were subject to biofouling, marked with sticky and slick surfaces of the wooden planks. There were Balanus sp. adhering to the wooden planks, but the sizes were small. Whitish larval colonies in a large quantity were also found (Figure 4). However, only a small fraction was showing the structure of macroscopic individuals. Therefore, the fouling was not observed and counted as macrofouling, except for one that occurred on the wooden plank substrate in control P6 on the tenth day of observation, with 18 Balanus sp. spotted. In treatments P1, P2, and P5, only 8, 6.3, and 6.6 Balanus sp. were attached to the wooden plank, respectively, while in treatment P3 and P4, only 3 and 1 Balanus sp. were spotted (Figure 5).

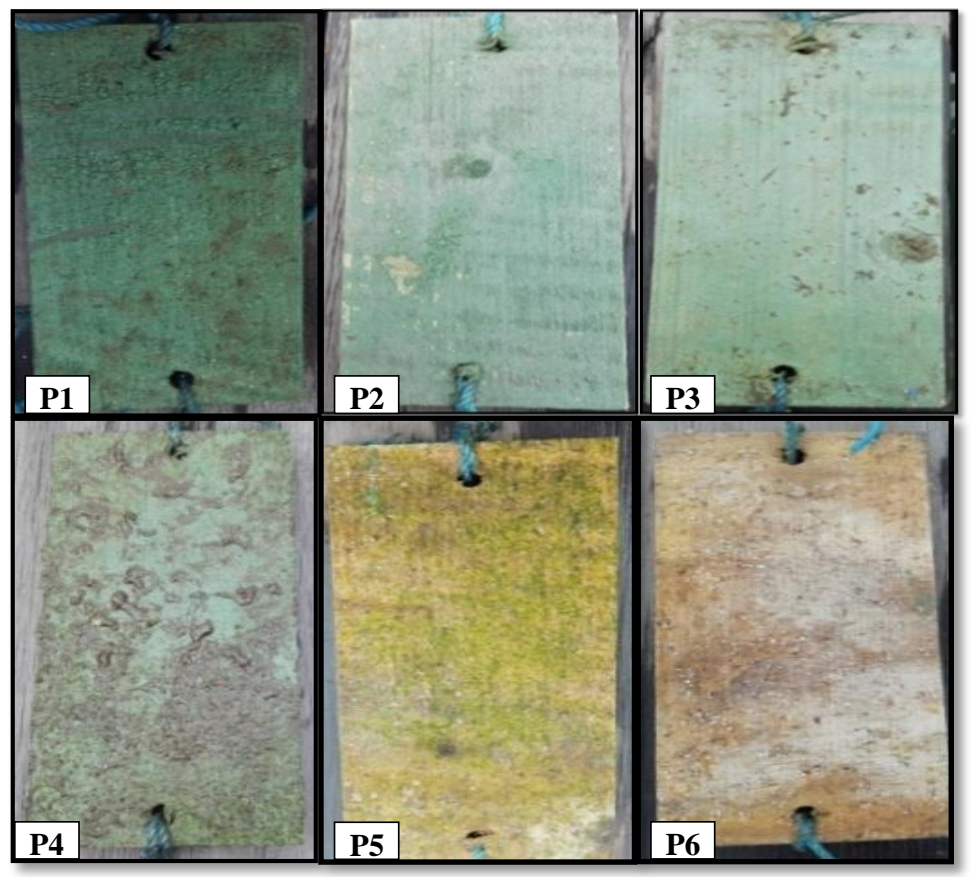

Figure 4. Appearance of wooden plank surfaces after being treated and immersed into the seawater for 10 days: P1: $100 \%$ paint; P2: $25 \%$ extract, $75 \%$ paint; P3: $50 \%$ extract, $50 \%$ paint; $\mathrm{P} 4: 75 \%$ extract, $25 \%$ paint; P5: 100\% extract; and P6: control (no paint and extract). 


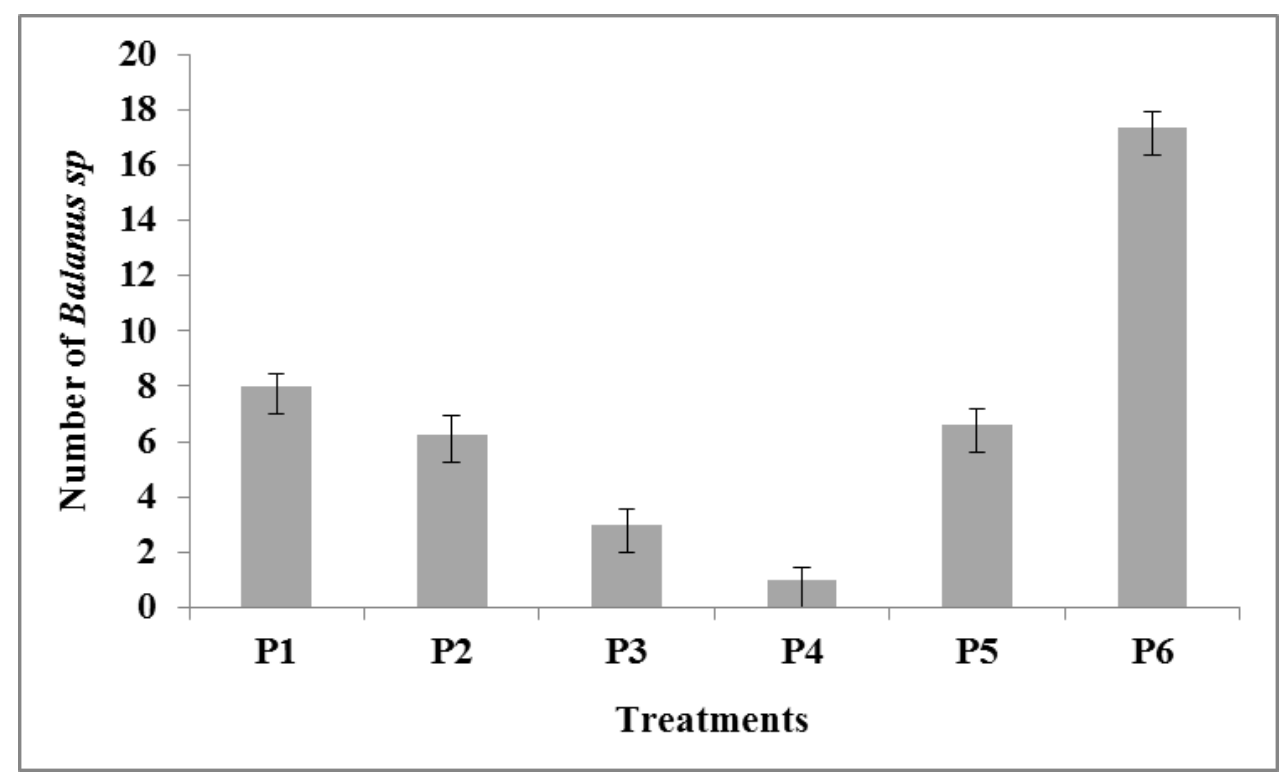

Figure 5. Number of Balanus sp. attached to the wooden plank on 10 days of submersion. P1: $100 \%$ paint; P2: $25 \%$ extract, $75 \%$ paint; P3: $50 \%$ extract, 50\% paint; P4: 75\% extract, $25 \%$ paint; P5: $100 \%$ extract; and P6: control (no paint and extract).

In the $20^{\text {th }}$ day observation, the number of Balanus sp. attached was clearly visible on the plank surfaces. Coarse, dark shells attached to the substrates were especially apparent in treatment P6 (Figure 6). A number of Balanus sp. was attached in all treatments, but at varying rates. The least numbers of Balanus sp. were found in treatments $\mathrm{P} 4, \mathrm{P} 3$, and $\mathrm{P} 2$ as many as 4.3, 14.6, and 52, respectively, while the largest was found in treatment $\mathrm{P} 1$ as many as 66.6. The number of Balanus sp. in control P6 was even larger (94.3) (Figure 7). 


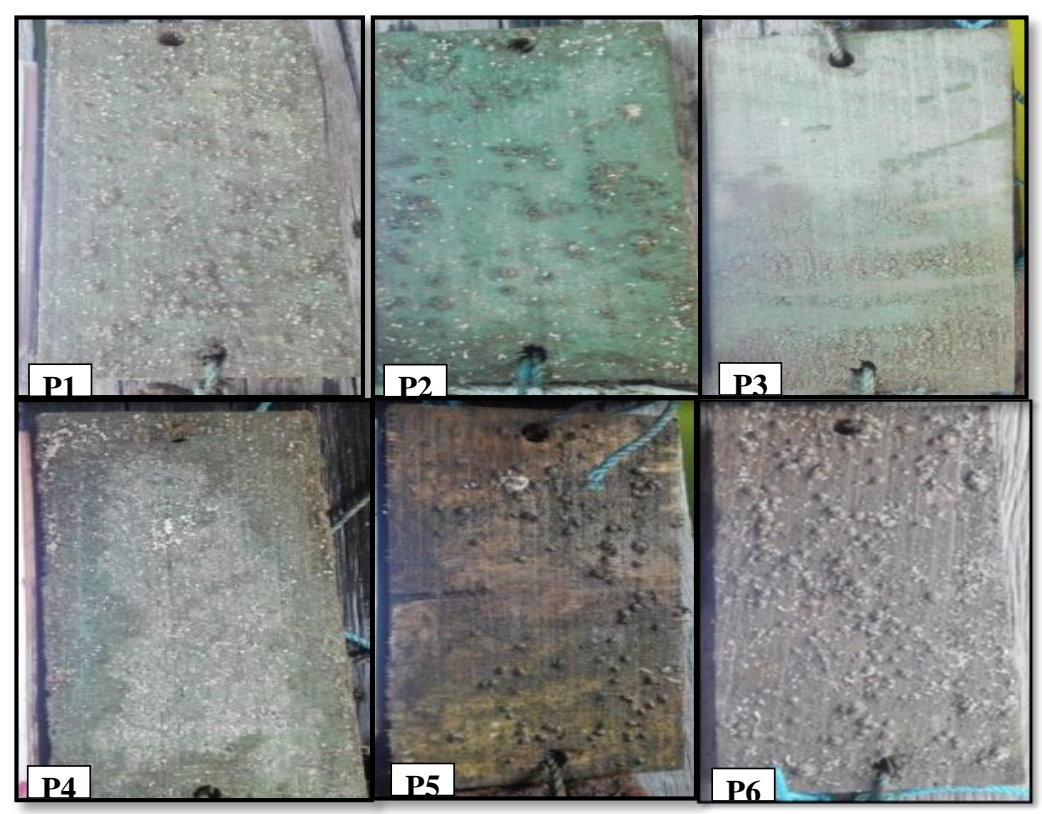

Figure 6. Appearance of wooden plank surfaces on $20^{\text {th }}$ day of observation after submersion in the seawater P1: $100 \%$ paint; P2: $25 \%$ extract, $75 \%$ paint; P3: 50\% extract, 50\% paint; P4: 75\% extract, $25 \%$ paint; P5: 100\% extract; and P6: control (no paint and extract).

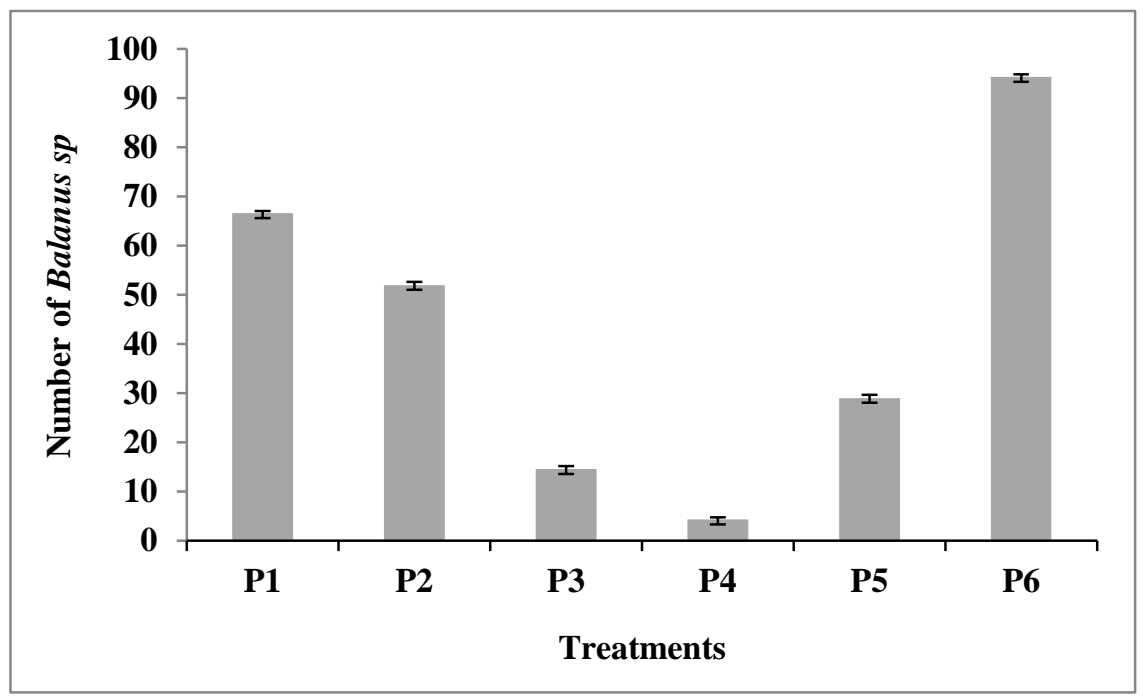

Figure 7. Number of Balanus sp. attached to the wooden plank on $20^{\text {th }}$ day of observation P1: $100 \%$ paint; P2: $25 \%$ extract, $75 \%$ paint; P3: 50\% extract, 50\% paint; P4: 75\% extract, $25 \%$ paint; $\mathrm{P} 5: 100 \%$ extract; and P6: control (no paint and extract).

In the observation on day 30 , the Balanus sp. density on the plank surfaces in treatments P1, P2, P5, and P6 increased, marked with acorn barnacles adhering to the substrates (Figure 8). The smallest numbers were found in treatments P4 and P3 as many as 12.3 and 24, respectively. The numbers of Balanus sp. in 
treatments P1, P2, and P5 were 102.3, 73.6, and 48.3, respectively, while control (P6) had the most Balanus sp. with 135.6 (Figure 9).

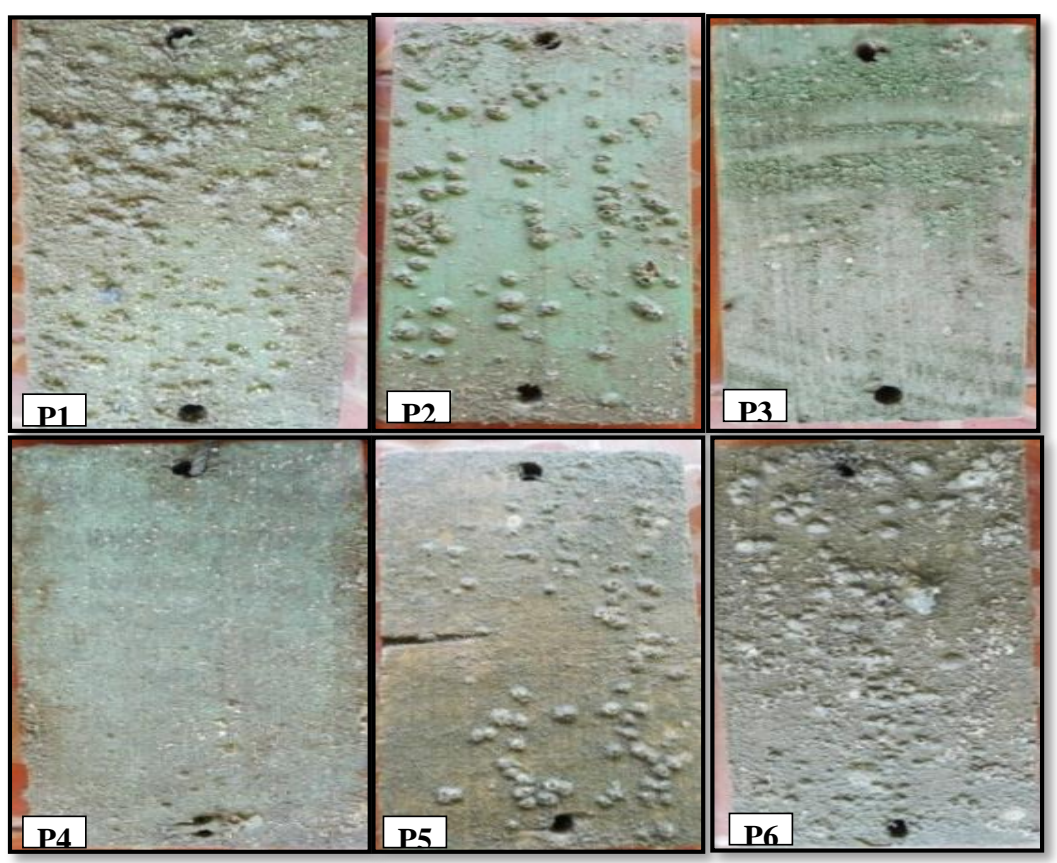

Figure 8. Appearance of wooden plank surfaces on day 30 after submersion P1: $100 \%$ paint; P2: $25 \%$ extract, $75 \%$ paint; P3: 50\% extract, 50\% paint; P4: 75\% extract, 25\% paint; P5: $100 \%$ extract; and P6: control (no paint and extract).

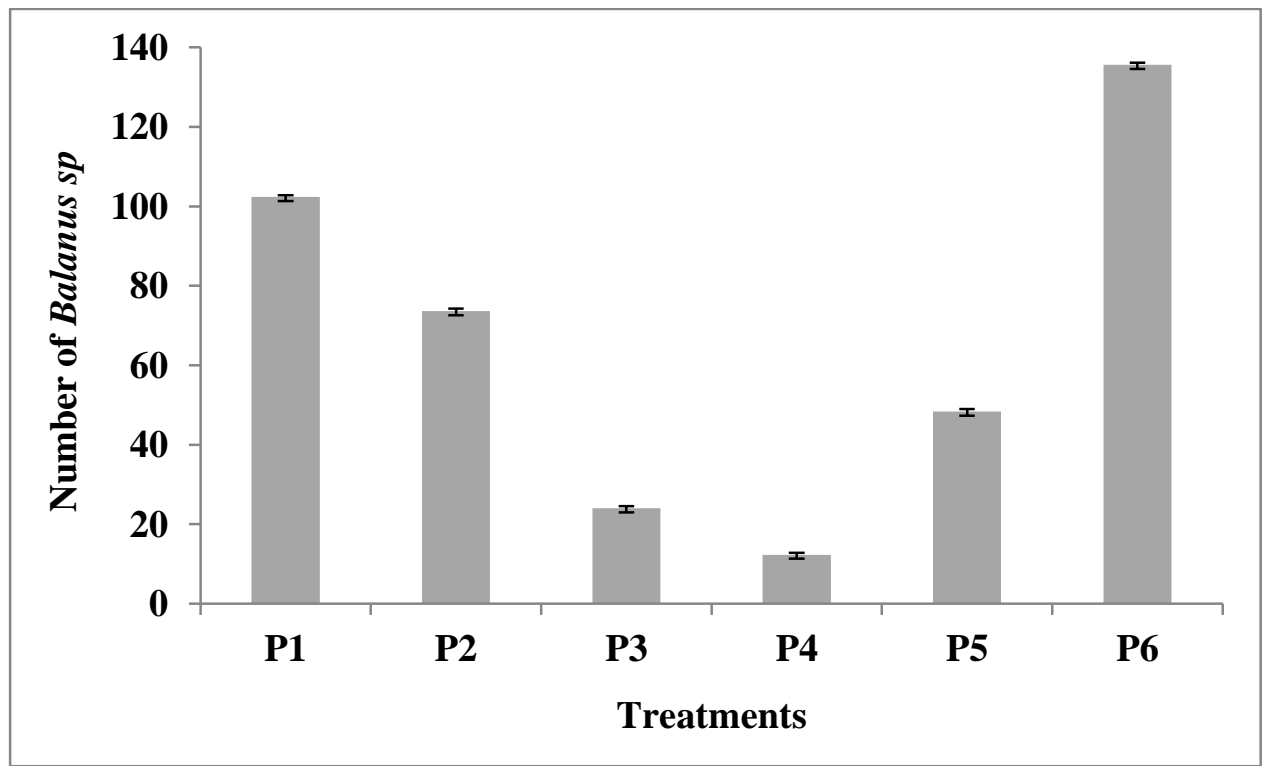

Figure 9. Number of Balanus sp. attached to the wooden plank on $30^{\text {th }}$ day P1: 100\% paint; P2: 25\% extract, 75\% paint; P3: 50\% extract, 50\% paint; P4: 75\% extract, $25 \%$ paint; P5: 100\% extract; and P6: control (no paint and extract). 
Based on the percentage of the number of Balanus sp. attached to the wooden plank in the last observation on the $30^{\text {th }}$ day, then the treatment P4 $(75 \%$ extract, $25 \%$ paint) exhibited the highest effectiveness in inhibiting fouling Balanus sp. on wooden planks at 3\%, followed by treatment P3 (50\% extract, $50 \%$ paint) at $6 \%$, treatment $\mathrm{P} 5$ (100\% extract) at $12 \%$, treatment $\mathrm{P} 2$ (25\% extract, $75 \%$ paint) at $19 \%$, treatment $\mathrm{P} 1$ (100\% paint) at 26\%, and control P6 (no paint and extract) at $34 \%$ (Figure 10).

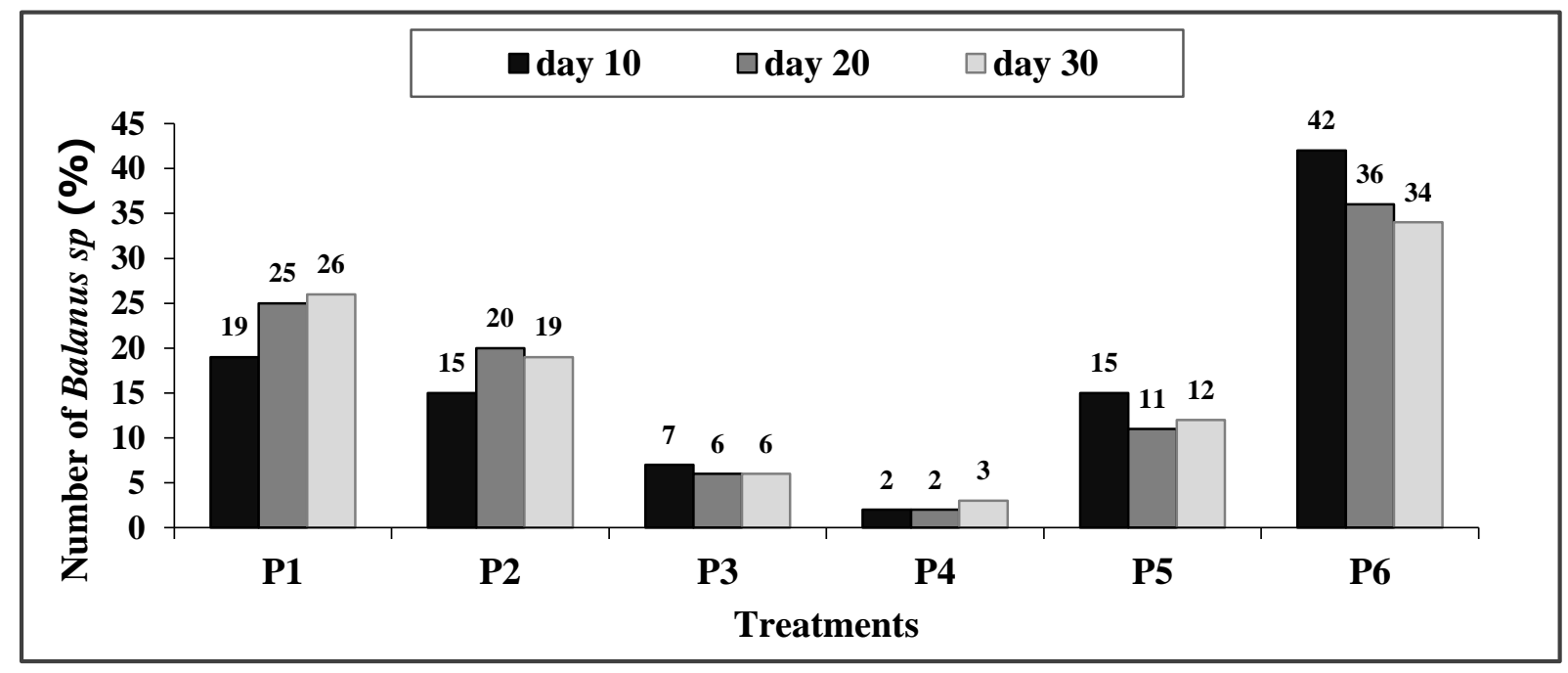

Figure 10. The effectiveness of each treatment in the inhibition of fouling Balanus sp. on wooden planks with treatments: P1: 100\% paint; P2: 25\% extract, 75\% paint; P3: 50\% extract, 50\% paint; $\mathrm{P} 4:$ 75\% extract, 25\% paint; P5: 100\% extract; and P6: control (no paint and extract).

\section{DISCUSSION}

\section{Extraction yield}

An extract yield value of $27.6 \%$ indicated that methanol was a good solvent for obtaining bioactive compounds that are polar molecules (Sastry and Rao, 1994; Septiana and Ari, 2012). S. duplicatum generates bioactive compounds that tend to be polar rather than non-polar, while methanol, which is a polar solvent, will bind the hydrogen in bioactive compounds. As a result, methanol allows easier bioactive compounds extraction than n-hexane solvent (Santi et al., 2014; Fahruddin et al., 2019). The bioactive compounds contained in S. duplicatum like alkaloids, saponins, quinones, phenols, steroids, and flavonoids are deterrent to organism growth (Sastry and Rao, 1994). Based on the laboratory bioassays conducted, these metabolic compounds were found to not only be toxic to a number of organisms, but also be cytotoxic and antimicrobial (Targett et al., 1986). 


\section{Reason for using teak plank and green paint}

Consideration was given to the selection of teak for this study as the type of timber that was used would influence the fouling organisms adhesion. According to Boesono (2008), teak-based materials are easy for fouling organisms to attach to on accounts of the materials elasticity and lack of chemicals that allow resistance to fouling organisms. In addition, the use of wooden planks is in accordance with boats or ships as well as pier support poles in Indonesia, especially in the islands in the Province of South Sulawesi, that are made mostly of wooden boards (Lanoeroe et al., 2005; Latifah et al., 2019).

The paint used was dark green paint for the reason that macrofouling adhesion can be affected by the selection of the paint color, and in this study, green paint was used in the paint-extract mixture (Rafael et al., 2014). Paints of dark colors are favorable to biofouling adhesion process. Fouling organisms are fonder of dark colors like brown, black, red, and green than bright colors like orange, yellow, and white. As stated by Almeida et al. (2007), dark colors have higher light absorbance rates and allow heat and light absorbance by the substrate. Organisms like barnacles demonstrate aversion to bright colors because in the larval phase, they are negatively phototrophic, which means they avoid light (Rafael et al., 2014).

\section{Anti-macrofouling activity of $S$. duplicatum extract}

On day 10, the wooden planks felt slippery to the touch. This indicated that microfouling organisms that secreted mucopolysaccharides attached themselves to the wooden planks. Biofouling occurs due to accumulation of nutrients on the substrate surfaces (Kerr et al., 1999). First, these nutrients attract microfouling organisms, then the accumulated organisms propagate and provide a source of nutrition for the development of higher-trophic-level multicellular organisms to the substrate (Myers et al., 2006; Bell et al., 2015). The bacterial biofilm on the substrate surfaces plays an important role in the adhesion and metamorphosis of some invertebrate larvae (Maki et al., 1988).

The treatment P4 (extract/paint ratio of 3:1) was the most effective in inhibiting macrofouling adhesion until day 30 with 12.3 Balanus sp. attached, followed by P3 (extract/paint ratio of 1:1) with 24 Balanus sp. attached. This suggested that increasing the $S$. duplicaticum extract portion in the mixture applied on the wooden substrate would influence the outcome.

That being said, the application of $100 \%$ extract was less effective in inhibiting Balanus sp. adhesion than the application of treatments P3 and P4, in which extracts were mixed with paint. $S$. duplicatum extract alone without paint would not stick to the planks for a long time, causing the anti-fouling activity to last only for a short time (Schultz, 2007; Boesono, 2008). Similarly, the application of $100 \%$ paint in treatment P1 was also proven ineffective in inhibiting the adhesion of macrofouling, showing the number of Balanus sp. attached more than $26 \%$. 
Treatment P4 showed the highest effectiveness in inhibiting Balanus sp. adhesion, proving that the bioactive compounds contained in the extract possessed the ability to inhibit the attachment of Balanus sp. in the sea. The differences in the quantity and the rate of bioactive compounds release led to the differences in the number of Balanus sp. between treatments, when extract was added to paint in varying quantities. According to Burgess et al. (2003), the paint will facilitate in the rate of release of antifouling active compounds from the extract and therefore, when the extract is incorporated into a paint, active components that are released from the painted surface wil be against a range of target organisms. In a previous study, extracts of Renilla reniformis, which is the sea pansy, that were added to paint and encapsulated in microtubules were found to be effective in controlling biofouling in the marine environment (Price et al., 1992), and paint formulations incorporating extracts of sponges were also shown to be active to inhibit macrofouling in barnacle settlement assays (Willemsen and Ferrari, 1993). In a separate study, extract of sponges was shown to be active against macrofouling when it was mixed with abietic acid, which is one of the main ingredients of paint and usually coated onto panels (Bakus et al., 1994). It was also stated by Matsumura et al. (2000) in the field trials that the paints had effect on either the onset or degree of macrofouling.

According to Holmström and Kjelleberg (1999), bioactive compounds produced by several marine organisms can inhibit the settlement or development of a range of surface colonizing species. This occurred because the bioactive compounds are able to cause disturbance to cell wall formation, which in turn, can lead to death of colonizing species (Johnson et al., 2019). Moreover, quinone in $S$. duplicatum is destructive to cell membranes, thus causing impediment to initiate growth and attachment on a substrate (Ganesan et al., 2008). This mechanism makes bioactive compounds able to inhibit the attachment of biofouling (Batubara et al., 2016; Johnson et al., 2019). On this account, the crude extract of $S$. duplicatum can be used as an antifouling agent containing bioactive compounds that are effective in controlling marine organisms settlement (Ganesan et al., 2008; Silkina et al., 2009).

\section{CONCLUSION}

The $S$. duplicatum extraction with methanol generated a high yield value of $27 \%$, with a dry weight of $306 \mathrm{~g}$ and an extract weight of $85 \mathrm{~g}$. Based on the last observation on the $30^{\text {th }}$ day, mixture of extract and paint was more effective in settlement inhibition of Balanus sp. In the treatment of P4 (extract 75\%, paint $25 \%$ ), the number of the Balanus sp. attached was only 3\%. It was the lowest compared to in other treatments. Treatment P1, which only used paint, showed $6 \%$ of Balanus sp attached, while treatment P5, which only used S. duplicatum extract, showed $12 \%$ of Balanus sp. attached. This shows that the combination of extracts containing bioactive compounds with paint will be more effective in 
inhibiting the attachment of macrofouling rather than only extracts or only paints because in the mixture, the paint stimulates the release of the active component in the extract to control the barnacles settlement on the substract. This work demonstrated the potential of $S$. duplicatum extract as paint coating and provide a solution to prevent macrofouling settlement on materials in the sea.

\section{ACKNOWLEDGEMENTS}

The researchers would like to thank the Dean of Faculty of Mathematics and Natural Sciences, Hasanuddin University, Makassar, Indonesia for the implementation of this study.

\section{REFERENCES}

Abarzua, S., and Jakubowski, S. 1995. Biotechnological investigation for the prevention of biofouling. Marine Ecology Progress Series. 123: 301-312. https://doi.org/10.3354/meps123301

Almeida, E., Diamantino, T.C., and De Sousa, O. 2007. Marine paints: the particular case of antifouling paints. Progress in Organic Coatings. 59(1): $2-20$.

Anil, A.C., Chiba, K., Okamoto, K., and Kurokura, H. 1995. Influence of temperature and salinity on larval development of Balanus amphitrite: implications in fouling ecology. Marine Ecology Progress Series. 118: 159-166.

Bangkedphol, S., Keenan, H.E., Davidson, C., Sakultantimetha, A., and Songsasen, A. 2009. The partition behavior of tributyltin and prediction of environmental fate, persistence and toxicity in aquatic environments. Chemosphere. 77(10): 1326-1332. https://doi.org/10.1016/j.chemosphere. 2009.09.046

Bakus, G.J., Wright, M., Khan, A.K., Ormsby, B., Gulko, D.A., Licuanan, W., Carriazo, E., Ortiz, A., Chan, D.B., Lorenzana, D., et al. 1994. Experiments seeking marine natural antifouling compounds. In: Thompson M.F., Nagabhushanam, R., Sarojini, R., and Fingerman, M. editors. Recent developments in biofouling control. Rotterdam: August Aimé Balkema. P. 373-381.

Bannister, J., Michael, S., Flora, B., and Nina, B. 2019. Biofouling in marine aquaculture: a review of recent research and developments. Biofouling. 24: 1-18. https://doi.org/10.1080/08927014.2019.1640214

Batubara, L., Kristina, T.N., and Rachmawati, B. 2016. Effectiveness of brown algae extract to reduce serum malondialdehyde and protein carbonyl levels in streptozotocin-induced sprague dawley rats. Sains Medika. 7(2): 43-48. 
Bell, C., Christopher, D.M., and Francesca, P. 2015. Barnacle settlement on rocky shores: substratum preference and epibiosis on mussels, Journal of Experimental Marine Biology and Ecology. 473: 195-201. https://doi.org/ 10.1016/j.jembe.2015.09.006

Bellas, J. 2006. Comparative toxicity of alternative antifouling biocides on embrsyos and larvae of marine invertebrates. Science of The Total Environment. 367(2-3): 573-585. https://doi.org/10.1016/j.scitotenv.2006. 01.028

Boesono, H. 2008. Effect of soaking duration on sticking organisms and modulus of elasticity in wood. Ilmu Kelautan. 13(3): 177-180.

Boxall, A.B.A., Comber, S.D., Conrad, A.U., Howcroft, J., and Zaman, N. 2000. Inputs, monitoring and fate modelling of antifouling biocides in UK estuaries. Marine Pollution Bulletin. 40(11): 898-905. https://doi.org/ 10.1016/S0025-326X(00)00021-7

Burgess, J.G., Boyd, K.G., Armstrong, E., Jiang, Z., Yan, L., Berggren, M., May, U., Pisacane, T., Granmo, A., and Adams, D.R. 2003. The development of a marine natural product-based antifouling paint. Biofouling. 19: 197-205. https://doi.org/10.1080/0892701031000061778

Chambers, L.D., Stokes, K.R., Walsh, F.C., and Wood, R.J.K. 2006. Modern approaches to marine antifouling coatings. Surface and Coatings Technology. 201(6): 3642-3652. https://doi.org/10.1016/j.surfcoat.2006. 08.129

Clare, A.S., Rittschof, D., Gerhart, D.J., Hooper, I.R., and Bonaventura, J. 1999. Antisettlement and narcotic action of analoguos of diterpene marine natural product antifoulant from octocorals. Marine Biotechnology. 1(5): 427-436.

Evans, S.M., Birchenough, A.C., and Branchato, M.S. 2000. The TBT ban: out of the frying pan into the fire?. Marine Pollution Bulletin. 40(3): 204-211. https://doi.org/10.1016/S0025-326X(99)00248-9

Fahruddin, F., Johannes, E., and Dwyana, Z. 2019. Potential of Thalassia hemprichii extract against growth of biofilm-forming bacteria. ScienceAsia. 45: 21-27.

Fernandez, M., Wagener, A.L.R., Limaverde, A.M., Scofield, A.L., Pinheiro, F.M., and Rodrigues, E. 2005. Imposex and surface sediment speciation: A combined approach to evaluate organotin contamination in Guanabara Bay, Rio de Janeiro, Brazil. Marine Environmental Research. 59(5): 435452. https://doi.org/10.1016/j.marenvres.2004.07.001

Fusetani, N. 2004. Biofouling and antifouling. Natural Product Reports. 21: 94104.

Ganesan, P., Kumar, C.S., and Bhaskar, N. 2008. Antioxidant properties of methanol extract and its solvent fractions obtained from selected Indian seaweeds. Bioresource Technology. 99(8): 2717-2723. https://doi.org/10. 1016/j.biortech.2007.07.005 
Giacomazzi, S., and Cochet, N. 2004. Environmental impact of diuron transformation: a review. Chemosphere. 56(11): 1021-1032. https://doi. org/ 10.1016/j.chemosphere.2004.04.061

Hellio, C., de la Broise, D., Dufossé, L., le Gal, Y., and Bourgougnon, N. 2001. Inhibition of marine bacteria by extracts of macroalgae: potential use for environmentally friendly antifouling paints. Marine Environmental Research. 52(3): 231-247. https://doi.org/10.1016/s0141-1136(01)00092-7

Holmström, C., and Kjelleberg, S. 1999. Marine Pseudoalteromonas species are associated with higher organisms and produce biologically active extracellular agents. FEMS Microbiology Ecology. 30(4): 285-293. https://doi.org/10.1111/j.1574-6941.1999.tb00656.x

IMO. 2002. Anti-fouling systems. International Maritime Organization, London. Johnson, M., Kanimozhi, S.A., Malar, T.R.J.B., Shibila, T., Freitas, P.R., Tintino, S.R., Menezes, I.R.A., da Costa, J.G.M., and Coutinho, H.D.M. 2019. The antioxidative effects of bioactive products from Sargassum polycystum C. Agardh and Sargassum duplicatum J. Agardh against inflammation and other pathological issues. Complementary Therapies in Medicine. 46: 1923. https://doi.org/10.1016/j.ctim.2019.06.014

Kadi A. 2005. Some notes on the occurrence of genus Sargassum in Indonesian waters. Oseana. XXX(4): 19-29.

Kerr, A., Beveridge, C.M., Cowling, M.J., Hodgkiess, T., Parr, A.C.S., and Smith, M.J. 1999. Some physical factors affecting the accumulation of biofouling. Journal of the Marine Biological Association of the United Kingdom. 79(2): 357-359. https://doi.org/10.1017/S00253154980 0040X

Kotrikla, A. 2009. Environmental management aspects for TBT antifouling wastes from the shipyards. Journal of Environmental Management. 90(1): S77-85. https://doi.org/10.1016/j.jenvman.2008.07.017

Lanoeroe, S., Kesaulija, E.M., and Rahawarin, Y.Y. 2005. The use of vascular plants as traditional boat raw material by Yachai tribe in Mappi Regency. Biodiversitas. 6(3): 212-216.

Latifah, H., Molo, H., and Apriani, J. 2019. Analysis of wood demand to making Bego traditional boats in Sumbawa District. Gorontalo Journal of Forestry Research. 2(2): 88-104.

Maki, J.S., Rittschof, D., Costlow, J.D., and Mitchell, R. 1988. Inhibition of attachment of larval barnacles, Balanus amphitrite, by bacterial surface films. Marine Biology. 97(2): 199-206. https://doi.org/10.1007/BF0039 1303 
Matsumura, K., Hills, J.M., Thomason, P.O., Thomason, J.C., and Clare, A.S. 2000. Discrimination at settlement in barnacles: laboratory and field experiments on settlement behaviour in response to settlement-inducing protein complexes. Biofouling. 16(2-4): 181-190. https://doi.org/10.1080/ 08927010009378443

Minchinton, T.E., and Mckenzie, L.A. 2008. Nutrient enrichment affects recruitment oyster and barnacles in a mangrove forest. Marine Ecology Progress Series. 354: 181-189. https://doi.org/10.3354/meps07178

Myers, J.H., Gunthorpe. L., Allinson, G., and Duda, S. 2006. Effects of antifouling biocides to the germination and growth of the marine macroalga, Hormosira banksia (Turner) Desicaine. Marine Pollution Bulletin. 52(9): 1048-1055. https://doi.org/10.1016/j.marpolbul.2006.01. 010

Pereira, C.L.V., Ximenes, C.F., Merlo, E., Sciortino, A.S., Monteiro, J.S., Moreira, A., Jacobsen, B.B., Graceli, J.B., Ginsburg, K.S., Junior, R.F.R., et al. 2019. Cardiotoxicity of environmental contaminant tributyltin involves myocyte oxidative stress and abnormal $\mathrm{Ca}^{2+}$ handling. Environmental Pollution. 247: 371-382. https://doi.org/10.1016/j.envpol. 2019.01.053

Perez, M., Blustein, G., Garcia, M., del Amo, B., and Stupak, M. 2006. Cupric tannate: a low copper content antifouling pigment. Progress in Organic Coatings. 55(4): 311-315. https://doi.org/10.1016/j.porgcoat.2005.11. 014

Price, R.R., Patchan, M., Clare, A., Rittschof, D., and Bonaventura, J. 1992. Performance enhancement of natural antifouling compounds and their analogs through microencapsulation and controlled release. Biofouling. 6(2): 207-216. https://doi.org/10.1080/08927019209386223

Rafael, S.P., Alessandra, F.B., Elaine, A., Carlos, A., and Carlos, A.F. 2014. Marine-friendly antifouling coating based on the use of a fatty acid derivative as a pigment. Materials Research. 17(3): 720-727. https://doi. org/10.1590/S1516-14392014005000032

Santi, I.W., Radjasa, O.K., and Widowati, I. 2014. Potential of Sargassum duplicatum seaweed as a source of antifouling compounds. Journal of Marine Research. 3(3): 274-284.

Sastry, V.M.V.S., and Rao, G.R.K. 1994. Antibacterial substance from marine algae. successive extraction using benzene, chloroform and metanol. Botanica Marina. 37(4): 357-360. https://doi.org/10.1515/botm.1994.37. 4.357

Schultz, M.P. 2007. Effects of coating roughness and biofouling on ship resistance and powering. Biofouling. 23(5): 331-341. https://doi.org/10. 1080/08927010701461974 
Septiana, A.T., and Asnani, A. 2012. Study of physiochemical of Sargassum duplicatum brown seaweed extract using various solvents and extraction methods. Jurnal Agrointek. 6(1): 22-28.

Silkina, A., Bazes, A., Vouvé, F., Tilly, V.L., Douzenel, P., Mouget, J.L., and Bourgougnon, N. 2009. Antifouling activity of macroalgal extracts on Fragilaria pinnata (bacillariophyceae): a comparison with diuron. Aquatic Toxicology. 94(4): 245-254. https://doi.org/10.1016/j.aquatox. 2009.07.004

Targett, N.M., Targett, T.E., Vrolijk, N.H., and Ogden, J.C. 1986. Effect of macrophyte secondary metabolites on feeding preferences of the herbivorous parrotfish. Marine Biology. 92(1): 141-148. https://doi.org/ 10.1007/BF00392756

Willemsen, P.R., and Ferrari, G.M. 1993. The use of anti-fouling compounds from sponges in anti-fouling paints. Surface Coatings International. 10: 423-427.

Yebra, D.M., Kiil, S., and Dam-Johansen, K. 2004. Antifouling technology-past, present and future steps towards efficient and environmentally friendly antifouling coatings. Progress in Organic Coatings. 50(2): 75-104. https://doi.org/10.1016/j.porgcoat.2003.06.001

Yule, A.B., and Walker, G. 1984. The adhesion of the barnacle, Balanus balanoides, to slate surfaces. Journal of the Marine Biological Association of the United Kingdom. 64(1): 147-156. https://doi.org/10.1017/ S0025315400059695 